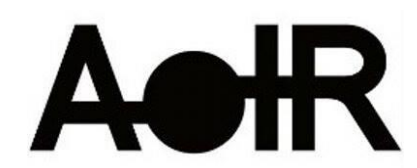

Selected Papers of \#AolR2021:

The 22nd Annual Conference of the

Association of Internet Researchers

Virtual Event / 13-16 Oct 2021

\title{
DEEP GAMES: ADDRESSING MENTAL HEALTH THROUGH INDEPENDENT VIDEOGAME DEVELOPMENT
}

\author{
Paolo Ruffino \\ University of Liverpool, Department of Communication and Media
}

Anxiety, depression, burnout and impostor syndrome are frequently reported among game-workers, and are exacerbated among independents and freelancers. At the Game Developers Conference 2020 the association Take This revealed that at least $50 \%$ of workers in the sector experience psychological burnout in their careers (Take This 2020). The UK Games Industry Census published in February 2020 discovered that $31 \%$ of respondents suffered anxiety and depression, compared to the national average of $17 \%$ (Taylor 2020, 48-52). The causes are identified in the instability of the professions in the game industry, frequent forms of harassment and micro-aggression, and stories of unfair treatment on the workplace. The lack of diversity in the field (still predominantly white and male) causes those who do not belong to the dominant gender, race and class to keep silent about these issues, which further impacts on their mental wellness (Harvey and Fisher 2013; Harvey 2019).

The paper draws on interviews with four London-based independent videogame developers who have engaged with the production of videogames about mental health. Interviews have been conducted online in 2020. The paper argues that conceiving, producing and releasing these games is understood by their makers as a strategy to establish relations with consumers, participants and other developers that could break the invisible barriers that prevent dialogues around mental wellness. More than being concerned with the outcome of their work, developers seek relations with other game workers and players through the process of making, researching, testing, and showing their videogames. The development of videogames about mental health is interpreted by the participants as facilitating exchanges of autobiographical experiences that are otherwise regulated by the norms of professional networking.

The present study contributes to scholarship on independent videogame development by exploring how research participants reflect on their affective relations with labour and how their responses mobilise the debates surrounding mental health. In the late 2000s and early 2010 s the aspiration of working independently at a videogame became more prominent in Western economies, and intersected with the availability of online

Suggested Citation (APA): Ruffino, P. (2021, October). Deep Games: Addressing mental health through independent videogame design. Paper presented at AoIR 2021: The 22nd Annual Conference of the Association of Internet Researchers. Virtual Event: AolR. Retrieved from http://spir.aoir.org. 
distribution platforms, crowdfunding, and freely available tools of production (Crogan 2018; Keogh 2015; Ruffino 2021). In the United Kingdom the effects of such a technological and social imaginary are particularly visible. According to industry representative UKIE, up to $95 \%$ of the workforce in the videogame sector in the UK is employed in small or micro-companies, and is often self-funding their initiative (UKIE $2018,25)$. Working individually at a videogame is not a new practice, but it is now becoming the standard for videogame developers, at least at some stage in their careers (Vanderhoef 2020).

Aspiring independent developers must comply with the entrepreneurial and neoliberal practices that determine the existence and survival of their job. In this process, they are expected to frame their passion towards work through a 'moral calculus', where vocational and profit-driven labour must be rightly balanced (Chia 2019). Independent developer are dependent on the labour market, which, despite claims of it being unregulated and open to all, presents a certain set of rules of engagement: it becomes necessary to comply with the rules of the cultural intermediaries, of social media and other contexts of PR and marketing, and appear in first person at multiple publicity, promotion, and networking events (Parker, Simon and Whitson 2017). These tasks demand time and effort, especially since the support originally provided by the professional figure of the producer has been eliminated in independent careers (Whitson, Simon and Parker 2018). The cultural labour of the independent developer is often invisible, deprived of mentoring schemes or clear patterns of progression, characterized by long working hours spent on networking and fundraising. Independent developers have marginal agency when it comes to deciding whether, and how, they are going to appear to players, other indies, and the general public. Yet, they need to be prepared to take all the responsibility for their products, public actions, and statements.

It is within this context that independent gaming and its failures are discussed as individual affairs. These failures typically give rise to social, psychological, and emotional crises, and frequently force independent developers to abandon their projects, social media presence, or, in some cases, even their careers. The dynamics of distribution and marketization of videogame products give rise to the praising and shaming of specific individuals, while treating each story as a separate case, attributable to the (successful or otherwise) life choices of a single person.

The paper analyses how four independent game designers have been responding to these systemic contradictions that promise personal emancipation, creative control, and economic success, while simultaneously rendering these almost entirely unachievable (Bulut 2020). Designing games on mental health is seen by the developers as a personal solution to tackle their anxieties and fears. Ultimately, the purpose of their project consists in establishing relations with others from where the (in)visibility of mental health can be addressed, and possibly dealt with, as a systemic issue of the videogame industry.

The research offers a number of findings and opens new questions. First, the participants acknowledge that game-making has become more individualised as a result of the emergence of independent development and of the vision of the auteur in game design, and that these tendencies have been increasing individual pressures and further 
exacerbating the mental distress of game workers. At the same time, their responses are articulated drawing on their personal life stories and on their autobiographical selfreflexivity. They believe that articulating personal life stories in their games, and in the ways they talk about their work, could enable new relations with others and bring to a better, fairer and more inclusive videogame industry. Their solutions are partly consistent with the vision of the auteur, but are orientated towards re-enabling their individual agency for the creation of new contexts of intimate exchanges.

Second, their accounts show that contexts of physical co-presence (such as festivals, game jams, research and collaboration centres) are vital for enabling social connections. These places 'make work real' as they make it immediately 'relatable' to others, in the words of one of the interviewees, and enable a dialogue that would otherwise remain unspoken. The emphasis put on physical co-presence and proximity as enabling dialogues around mental health raises further questions in times of social isolation. The effects of the COVID-19 pandemic on the lives and work of independent videogame developers might have serious repercussions not just on their mental health, but on the very possibility of discussing and addressing issues of mental distress.

\section{References}

Bulut, Ergin. 2020. A Precarious Game: The Illusion of Dream Jobs in the Video Game Industry. Ithaca (NY): Cornell University Press.

Chia, Aleena. 2019. "The Moral Calculus of Vocational Passion in Digital Gaming". Television and New Media 20(8): 767-777.

Crogan, Patrick. 2018. "Indie dreams: Video games, creative economy, and the hyperindustrial epoch". Games and Culture 13(7): 671-689.

Harvey, Alison. 2019. "Becoming gamesworkers: Diversity, higher education, and the future of the game industry". Television \& New Media 20(8): 756-766.

Harvey, Alison and Fisher, Stephanie. 2013. "Intervention for inclusivity: Gender politics and indie game development". Loading... Journal of the Canadian Game Studies Association 7 (11): 25-40.

Keogh, Brendan. 2015. "Between triple-A, indie, casual, and DIY: Sites of tension in the videogames cultural industries" in Oakley, K and O'Connor, J (eds.), The Routledge companion to the cultural industries (Routledge Media and Cultural Studies Companions). London: Routledge: 152-162.

Parker Felan, Simon, Bart, Whitson, Jennifer. 2017. "Megabooth: The cultural intermediation of indie games." New Media and Society 20(5): 1953-1972.

Ruffino, Paolo (ed.). 2021. Independent Videogames: Cultures, Networks, Techniques and Politics. London: Routledge. 
Take This. 2020. "Mental Health State of the Industry: Past, Present \& Future. GDC Vault." Accessed April 12. https://gdcvault.com/play/1026622/Mental-Health-State-of-the

Taylor, Mark. 2020. UK Games Industry Census - understanding diversity in the UK games industry workforce. London: UKIE.

UKIE 2018. "The UK Video Games Sector A Blueprint for Growth." Accessed April 12. https://ukie.org.uk/sites/default/files/Ukie\%20Blueprint\%20for\%20growth.pdf.

Vanderhoef, John. 2020. Passion, Pixels, and Profit: The New Creative Economy of Indie Game Production. Michigan: University of Michigan Press.

Whitson, Jennifer, Simon, Bart, Parker, Felan. 2018. "The Missing Producer: Rethinking indie cultural production in terms of entrepreneurship, relational labour, and sustainability." European Journal of Cultural Studies. https://doi.org/10.1177\%2F1367549418810082. 